\title{
THE UTILIZATION OF CAVEAT EMPTOR IN CERCLA PRIVATE PARTY CLEANUPS
}

\author{
Michael ANDREw O'HARA ${ }^{*}$
}

\section{INTRODUCTION}

Congress adopted the Comprehensive Environmental Response, Compensation and Liability Act of 1980 ("CERCLA") ${ }^{1}$ to help alleviate the problems created by contaminated waste sites and to provide for fast and effective cleanup of hazardous waste. CERCLA grants authority to certain parties to initiate cleanup efforts and provides retroactive, strict, and joint and several liability to ensure that the costs of the cleanup are borne by parties causally responsible for the waste. Because any given unit of commercial real property is likely to have had several owners and/or lessees, each possibly contributing to on-site contamination, allocating responsibility for cleanup costs presents a unique challenge.

CERCLA is ambiguous concerning the use of equitable principles in allocating costs to various parties. Many courts have interpreted CERCLA to proscribe the use of equitable defenses, including caveat emptor. ${ }^{2}$ Without caveat emptor, CERCLA allows a purchaser of commercial property, with actual or constructive notice of contamination, to buy the property for a discounted price reflecting environmental defects, and then sue the seller for at least partial restitution of cleanup costs. Thus, the seller may pay for the cost of cleanup twice: once in the discounted selling price and again if held strictly liable for the cleanup costs incurred by the purchaser. The seller acts as an unwitting insurer for the purchaser by assuming all of the risk of exposure for preexisting environmental contamination. The purchaser insulates itself from risks that it should have considered when the transaction was undertaken, and may obtain a double recovery.

A double recovery is both unfair to the seller and economically inefficient. Society creates aggregate demand and supply for transactions dealing with contaminated, or possibly contaminated, property. Like all markets, the market

Copyright $(1993$ by Law and Contemporary Problems

* Associate, Ropes \& Gray, Boston, Massachusetts.

1. 42 U.S.C. \$\$ 9601-75 (1988 \& Supp. II 1990), as amended by the Superfund Amendments and Reauthorization Act ("SARA"), Pub. L. No. 99-499, 100 Stat. 1613 (1986). The act is commonly referred to as "Superfund."

2. "Caveat emptor" means "let the buyer beware." See infra note 52 and accompanying text. 
for real property considers the costs inherent in supplying the good. Because, the cost of a cleanup is not accurately factored into the price of the property, the market will not adequately reflect the total cost of the property. The cost of the cleanup, if performed by the government, will be shouldered by society and not by the parties to the transaction. This is an "externality." 3 CERCLA's liability scheme "internalizes" this cost by requiring the party (or parties) involved in causing the site's contamination to pay the cost of cleanup, regardless of fault. ${ }^{4}$ In the CERCLA liability scheme, however, the internalization occurs ex post, in that parties do not include the cleanup as an actual cost until the legal system imposes the costs upon a party. As a result, parties involved in a transaction perceive the cost of the property to be lower than it is, creating a diseconomy, or a market distortion, and leading to a greater number of sales than would be desired had the true costs been understood. Assuming that all contaminated property involved in these transactions will someday need to be cleaned, society will have been involved in far more property transactions than desired. This misallocation of societal resources is a direct result of the lack of complete information regarding the entity's inherent costs. Transforming CERCLA from an $e x$ post to an ex ante internalization scheme, at least with regard to private parties, would help to remove this misallocation.

Today, thirteen years after CERCLA's enactment, one can assume that both parties to a commercial land transaction are aware of their potential liability under CERCLA. Due to the threat of an Environmental Protection Agency ("EPA") enforcement action against the purchaser when he or she becomes an "owner," an incentive exists for the purchaser to investigate the site prior to purchase: the innocent owner defense. ${ }^{5}$ However, better incentives are required for sellers voluntarily to disclose fully and for purchasers to account for environmental costs and risks more accurately in cases where the EPA is not involved. In fact, in the absence of effective indemnity, the possibility of the purchaser obtaining a double recovery acts as a disincentive to full disclosure. Wherever possible, it would be to the seller's advantage to conceal known contamination in the hope that an inflated price would cover any potential CERCLA exposure.

In the case of private party transactional law, fairness and economic rationality suggest that we move to a system of full disclosure of contamination and that the legal institution require the purchaser to consider this risk when agreeing to a price. CERCLA should be interpreted by the courts to allow a fully disclosing seller to assert the equitable defense of caveat emptor against the

3. Mansfield calls this form of externality an "external diseconomy of production." EDWIN MANSFIELD, MICROECONOMICS: THEORY AND APPLICATIONS 475-76 (5th ed. 1985).

4. For the seminal discussion on utilizing liability schemes to internalize an externality, see ARTHur C. Pigou, The ECONOMics OF Welfare 183-96 (4th ed. 1932).

5. See 42 U.S.C. $\$ 9607(b)(3)$ (1988). This defense protects a purchaser, in certain circumstances, from liability in restitution to third parties who have cleaned up the purchaser's property. See infra note 18. 
purchaser in the liability phase of a private party suit to recover cleanup costs. ${ }^{6}$ Caveat emptor's proscription of ex post cost recovery will provide an incentive for the purchaser to assess accurately the potential environmental costs and to account for those costs in the purchase price, preventing the purchaser from obtaining a double recovery.

This article discusses the applicability of equitable defenses in private party CERCLA actions. Part II sketches the purpose and origin of CERCLA with a view toward establishing the special place of equity in private party claims. Part III discusses equity generally, and the equitable defense of caveat emptor specifically. Part IV reviews CERCLA's effects on the market for real property transactions. Part $\mathrm{V}$ argues that applying caveat emptor to CERCLA private party claims would better effectuate the goal of economic efficiency in the market for real property. Part VI discusses and analyzes those cases that have disallowed caveat emptor in the liability phase of CERCLA, those that disallow it entirely, and those that have decided in favor of caveat emptor and other equitable defenses. Part VII concludes that the defense is available for the courts to use at their discretion and that holding the purchaser responsible for the property he or she purchases is economically and equitably beneficial.

II

\section{CERCLA}

\section{A. Purpose and Origin}

In 1979, Congress began "searching for solutions to the problems of how to clean up old hazardous waste dump sites that now threaten our environment, and for ways to clean up future spills of hazardous wastes."7 Much of the concern that ultimately resulted in the creation of CERCLA developed with the discovery of the human health threats posed by the hazardous waste dumps at New York's Love Canal, Missouri's Times Beach, and Kentucky's Valley of the Drums. $^{8}$ The congressional hearings and the original drafts of the proposed House and Senate bills also evidence a concern for remediation to people who

6. The government's overriding need to fund future cleanups through recovery of prior cleanup costs is a strong policy argument for distinguishing between government and private party actions under CERCLA. See infra text accompanying notes 27-31.

7. Administration Testimony on S. 1480 Before the Subcomms. on Environmental Pollution and Resource Protection, Senate Comm. on Environment and Public Works, 96th Cong., 1st Sess. 1 (1979) (statement of Sen. John C. Culver), reprinted in 1 COMM. ON ENV'T AND PUB. WORKS, 97TH CONG., 2D SESS., LEGISLATIVE HISTORY OF THE COMPREHENSIVE ENVIRONMENTAL RESPONSE, COMPENSATION, AND LIABILITY ACT OF 1980 (SUPERFUND), at 55 (1983) [hereinafter CERCLA LEG. HIST.].

8. Id. at 60, 86-90 (statement of Thomas C. Jorling, Assistant Administrator, Water and Waste Management, Environmental Protection Agency); S. REP. No. 96-848, 96th Cong., 2d Sess. 4-5 (1980), reprinted in 1 CERCLA LEG. HIST., supra note 7, at 311-12; H.R. REP. No. 96-1016, 96th Cong., 2d Sess., pt. 1, at 18-21 (1980), reprinted in 2 CERCLA LEG. HIST., supra note 7, at 49-52. See also JAN PAUl ACTON, UNDERSTANDING SUPERFUND, A PROgRess REPORT 1 (1989); Barbara Ann White, Economizing on the Sins of Our Past: Cleaning Up Our Hazardous Wastes, 25 Hous. L. REv. 899, 899900 (1988). 
were harmed by these sites, ${ }^{9}$ and for response and remediation of land contamination caused by petroleum. ${ }^{10}$ Both of these concerns were ultimately omitted from CERCLA, however. The latter was expressly omitted as a result of political maneuvering to pass the bill before outgoing President Jimmy Carter left office and Ronald Reagan entered. ${ }^{11}$

CERCLA provides methods by which the government can attain the congressional goal of reducing the threat to human health and the environment caused by hazardous waste. The statute provides for use of the Hazardous Substance Superfund, ${ }^{12}$ a trust fund derived from taxes levied on the manufacturers of petroleum, chemical feedstocks (the basal constituents of usable chemicals), and from a general corporate environmental tax. This fund is to be replenished either by awards won by the government against responsible parties or, when no responsible parties can be found, by future tax revenues. Because the EPA must spend funds before they are reimbursed, there is a limit to the amount of cleanups that can be undertaken by the EPA at any time. Due to this limit, and to Congress's desire to facilitate cleanups in general, CERCLA allows the EPA to issue administrative orders to private parties under section 106 "to secure such relief as may be necessary to abate such danger or threat."13 Those parties who have received a section 106 order to remediate must clean up the

9. The original Senate bill did not provide for personal third-party toxic tort remedies, 125 CONG. REC. 17,988 (1979) (statement of Sen. John C. Culver on Introducing S. 1480), reprinted in 1 CERCLA LEG. HIST., supra note 7, at 147, but it did provide for recovery of loss of income and out-of-pocket medical expenses. S. REP. No. 96-848, 96th Cong., 2d Sess., at 32 (1980), reprinted in 1 CERCLA LEG. HIST., supra note 7 , at 305,339 . This was partially due to the belief that state law was adequate in providing permanent remedies. See County Line Investment Co. v. Tinney, 933 F.2d 1508, 1517 (10th Cir. 1991); see also Artesian Water Co. v. New Castle County, 659 F. Supp. 1269, 1299-1300 (D. Del. 1987), affd, 851 F.2d 643 (3d Cir. 1988). The lack of third-party toxic tort remedies also reflected the belief that EPA "could protect more of the public by containing more of these sites than by addressing our scarce resources to one, two or three of these sites." Administration Testimony on S. 1480 Before the Subcomms. on Environmental Pollution and Resource Protection, Senate Comm. on Environment and Public Works, 96th Cong., 1st Sess. 6 (1979) (statement of Thomas C. Jorling, Assistant Administrator, Water and Waste Management, Environmental Protection Agency), reprinted in 1 CERCLA LEG. HIST., supra note 7, at 65 . The original bill also did not include third-party provisions because it was difficult to determine at any given time the total medical expenses caused by hazardous wastes. Id.

10. Administration Testimony on S. 1480 Before the Subcomms. on Environmental Pollution and Resource Protection, Senate Comm. on Environment and Public Works, 96th Cong., 1st Sess. 6 (1979) (statement of Thomas C. Jorling, Assistant Administrator, Water and Waste Management, Environmental Protection Agency), reprinted in 1 CERCLA LEG. HIST., supra note 7, at 86, 131-32.

11. "There is perhaps no more telling evidence of the supercharged political atmosphere that begat Superfund than that it was passed by a lame-duck Congress during the transition from a Democratic to a Republican administration." Roger C. Dower, Hazardous Wastes, in PUBLIC POLICIES FOR ENVIRONMENTAL Protection 151, 169 (Paul R. Portney ed., 1990).

CERCLA expressly excludes "petroleum, including crude oil or any fraction thereof which is not otherwise specifically listed or designated as a hazardous substance" from its definition of "hazardous substance." 42 U.S.C. \$ 9601(14) (1988).

12. The use of the Hazardous Substance Superfund is outlined in CERCLA \& 111. 42 U.S.C. \$ 9611 (1988 \& Supp. II 1990). See also 26 U.S.C. \& 9507 (1988 \& Supp. II 1990) (Internal Revenue Code authorizing the "Hazardous Substances Superfund"). While the EPA may use the fund for remediation of sites on the National Priority List ("NPL"), see below, it may also pursue fund-based cleanups for sites not on the NPL but in need of emergency response pursuant to CERCLA $\$ 104.42$ U.S.C. \& 9604(a)(4) (1988).

13. 42 U.S.C. $\$ 9606(a)(1988)$. 
subject site themselves and may then sue any other responsible parties under section $107(a)(4)(B)$ to recover costs not attributable to themselves. ${ }^{14}$ It is this same provision, section $107(\mathrm{a})(4)(B)$, that has been interpreted to allow a private cause of action without government intervention.

\section{B. CERCLA's Liability Scheme}

When any party remediates a site under CERCLA, it has recourse to the liability provisions of section 107 , which places retroactive,${ }^{15}$ strict,${ }^{16}$ and joint and several liability ${ }^{17}$ on owners ${ }^{18}$ and operators of contaminated sites, vessels,

\section{Id. § $9607(\mathrm{a})(4)(\mathrm{B})$.}

15. CERCLA has often been attacked on due process principles by defendants who charge that liability imposed ex post facto violates their constitutional right of fair notice. These attacks have been fruitless, however, as courts have found the retroactive legislation to be "supported by a legitimate legislative purpose." Pension Benefit Guaranty Corp. v. R. A. Gray \& Co., 467 U.S. 717, 729-30 (1984); see also United States v. Northeastern Pharmaceutical \& Chemical Co., 810 F.2d 726, 733 (8th Cir. 1986); United States v. Kramer, 757 F. Supp. 397, $428-31$ (D.N.J. 1991); United States v. Ottati \& Goss, Inc., 630 F. Supp. 1361, 1398 (D.N.H. 1985), affd in part and vacated in part, 900 F.2d 429 (1st Cir. 1990); United States v. Conservation Chemical Co., 619 F. Supp. 162, 213-14 (W.D. Mo. 1985).

16. See United States v. Price, 577 F. Supp. 1103, 1113-14 (D.N.J. 1983) ("Though strict liability may impose harsh results on certain defendants, it is the most equitable solution in view of the alternative-forcing those who bear no responsibility for causing the damage, the taxpayers, to shoulder the full cost of the cleanup."), cited in Kramer, 757 F. Supp. at 419. See also New York v. Shore Realty Corp., 759 F.2d 1032, 1042 (2d Cir. 1985); Artesian Water Co. v. Government of New Castle County, 659 F. Supp. 1269, 1277 (D. Del. 1987), affd, 851 F.2d 643 (3rd Cir. 1988).

Congress utilized strict liability not only due to its fairness, S. REP. No. 96-848, 96th Cong., 2d Sess., at 31-34 (1980), reprinted in 1 CERCLA LEG. HIST., supra note 7, at 305, 338-42 (the strict liability scheme "is to assure that the costs of injuries resulting from ... hazardous substances are borne by the persons who create such risks rather than the injured parties"), but also due to its capacity to make industry aware of the true economic costs of its endeavor. Id. at 34, reprinted in 1 CERCIA Leg. Hist, supra note 7 , at 341 .

17. CERCLA liability is said to be "joint and several, as a matter of federal common law." SUPERFUND AMENDMENTS AND REAUTHORIZATION ACT OF 1986, H.R. REP. No. 253(I), 99th Cong., 2d Sess. 74 (1986), reprinted in 1986 U.S.C.C.A.N. (99 Stat.) 2835, 2856. See also Ottati \& Goss, 630 F. Supp. at 1395-96; and Lewis M. Barr, CERCLA Made Simple: An Analysis of the Cases Under the Comprehensive Environmental Response, Compensation, Liability Act of 1980, 45 BUS. LAW. 923, 977-79 (1990) and cases cited therein.

18. 42 U.S.C. $\S 9607(\mathrm{a})(1)(1988)$. The enumerated defenses to $\S 107$ liability are limited to proving that the waste was caused by an act of God $(\$ 107(\mathrm{~b})(1))$, an act of war $(\$ 107(\mathrm{~b})(2))$, or an act or omission of a third party not associated with the party by contract $(\S 107(b)(3))$. 42 U.S.C. $\S$ 9607(b)(1)-(3). But, as one commentator points out:

Ordinarily, a landowner who purchases contaminated land would have no defense under the "act or omission of a third party" provision [section 107(b)(3)] because he would be considered in direct or indirect contractual relationship with previous landowners. The Superfund Amendments and Reauthorization Act of 1986, however, added a definition of contractual relationship to section 101(35), which provides for a limited measure of relief. It excludes innocent subsequent landowners, who made a diligent inquiry of site conditions, from the category of parties having a direct or indirect contractual relationship with previous owners. By this exclusion, a narrow group of innocent subsequent landowners have been provided with a statutory defense to strict liability.

Edmund B. Frost, Strict Liability as an Incentive for Cleanup of Contaminated Property, 25 Hous. L. REV. 951, 955 (1988) (citations omitted).

Current property owners who planned for potential environmental problems, but found no contamination through "diligent inquiry," are capable of obtaining a double recovery under CERCLA. 
or facilities, ${ }^{19}$ as well as any person ${ }^{20}$ who transported ${ }^{21}$ or accepted hazardous materials. ${ }^{22}$ The express defenses to section 107 liability are limited to proof by the party that the site's contamination was caused solely by an act of God, war, or an unrelated third party. ${ }^{23}$

CERCLA imposes restitutionary liability, traditionally considered an equitable remedy, ${ }^{24}$ by awarding to the cleaner "all costs of removal or remedial action incurred by the United States Government ... not inconsistent with the national contingency plan." 25 CERCLA also allows for restitution of "any other necessary costs of response incurred by any other person consistent with the national contingency plan.,26

These people belong to the "narrow group" described by Frost. Thirteen years after the enactment of CERCLA, the group of exempted landowners is probably incorrectly categorized as "narrow," as it is becoming increasingly obvious to sophisticated purchasers that it is beneficial to make a "diligent inquiry of site conditions." See, e.g., Johnine J. Brown, Keeping Clean: Avoiding Hazardous Waste Liability, in THE IMPACT OF ENVIRONMENTAL REgUlations ON BUSINESS TRANSACTIONS 211 (PLI Real Est. L. and Practice Course Handbook Series No. 322, 1988) [hereinafter PLI HANDBOOK]; David J. Hayes et al., Cercla Rights and Liabilities, in THE IMPACT OF ENVIRONMENTAL LAw ON REAL ESTATE AND OTHER COMMERCIAL Transactions 3 (A.L.I.-A.B.A. Course of Study Materials, 1991) [hereinafter A.L.I.-A.B.A. MATERIALS]; Joel S. Moskowitz, ENVIRONMENTAL LIABILITY AND REAL PROPERTY TRANSACTIONS: LAW AND PRACTICE $\$ 10.2$ (1989 \& Supp. 1991). The question left to be answered is what a party that does not uncover hazardous waste contamination during its inquiry must prove to be considered "diligent."

19. 42 U.S.C. $\S 9607$ (a)(1). The term "owner and operator," as defined by 42 U.S.C. $\S$ $9601(20)(A)$, does not include someone who "holds indicia of ownership primarily to protect his security interest in the vessel or facility." This has been controversial of late due to dicta in United States v. Fleet Factors, 901 F.2d 1550, $1557-58$ (11th Cir. 1990), which stated that a lender capable of persuading a company to take environmental precautions may be held liable under CERCLA for contamination caused by a bankrupt company it has foreclosed upon. EPA has proposed an addition to the National Contingency Plan which specifically limits lender liability. National Oil and Hazardous Substances Pollution Contingency Plan, 56 Fed. Reg. 28,798, at 28,810 (1991) (to be codified at 40 C.F.R. $\$ 300$ ).

20. 'The term 'person' means an individual, firm, corporation, association, partnership, consortium, joint venture, commercial entity, United States Government, State, municipality, commission, political subdivision of a State, or any interstate body." CERCLA § 101(21), 42 U.S.C. \& 9601(21).

21. 42 U.S.C. \& 9607 (a)(3).

22. Id. \& 9607(a)(4). CERCLA provides that all substances designated as "hazardous" or "toxic" under the Clean Air Act, 42 U.S.C. \& 7412(b) (Supp. II 1990), the Clean Water Act, 33 U.S.C. \& 1321(b)(2)(A) (1988 \& Supp. II 1990), the Resource Conservation and Recovery Act, 42 U.S.C. $\$ 6921$ (Supp. II. 1990), and the Toxic Substance Control Act, 15 U.S.C. \& 2606 (1988), as well as any other substances EPA deems appropriate, are hazardous wastes for the purposes of CERCLA. 42 U.S.C. § 9601(14). Unlike the Clean Water Act, CERCLA specifically excludes petroleum from its definition of hazardous substances. However, the definition does not include petroleum or petroleum products that are mixed with other hazardous substances or mixed with substances that produce a hazardous substance upon combination. The definition also does not include petroleum that has contaminated over time.

23. $\quad 42$ U.S.C. \& 9607 (b). See supra note 18.

24. See, e.g., United States v. Mottolo, 695 F. Supp. 615, 626-27 (D.N.H. 1988); see also Boeing Co. v. Aetna Casualty \& Surety Co., 784 P.2d 507, 517-19 (Wash. 1990) (Callow, J., dissenting) (indemnification agreements that expressly cover only "damages" incurred by the indemnitee do not include CERCLA recoveries because CERCLA allows for restitution and not for "damages"). Though the form of liability is considered restitutionary, not all agree to what extent this restitution is equitable in nature. See infra Part VI.

25. 42 U.S.C. \& 9607(a)(4)(A). See also The National Oil and Hazardous Substances Pollution Contingency Plan, 40 C.F.R. $\$ \$ 300.1-300.920$ (1992) [hereinafter National Contingency Plan or NCP].

26. 42 U.S.C. $\$ 9607$ (a)(4)(B) (emphasis added). Much controversy has arisen over what a private party must do to clean in a manner "consistent with the national contingency plan." On March 8, 1990, the EPA stated that it believes consistency "should be measured by whether the private party cleanup 
The significant attention drawn by hazardous waste contamination has produced intense pressure on the EPA to clean up sites and to recover Superfund expenses. Due to the need to replenish Superfund, public and private restitution actions for hazardous waste cleanups are fundamentally different. Under CERCLA, the EPA may recover costs of remediation ${ }^{27}$ or response, ${ }^{28}$ but a private party can recover only response costs. The EPA has recourse to Superfund ${ }^{29}$ for expenses incurred during a response to a release that poses a "substantial and imminent danger to the public health or welfare." also has recourse to Superfund for permanent remediation of sites listed on the National Priority List. ${ }^{31}$ The EPA uses the fund to investigate and clean sites; the government then brings actions against potentially responsible parties ("PRPs") to reimburse Superfund. ${ }^{32}$ It is clear that CERCLA's scheme of joint

has, when evaluated as a whole, achieved 'substantial compliance' with potentially applicable requirements, and resulted in a CERCLA quality cleanup." NCP, 55 Fed. Reg. 46,8793 (1990) (to be codified at 40 C.F.R. $\$ 300.700$ (c)). This test reflects the EPA's concerns that:

it is important to encourage private parties to perform voluntary cleanups of sites and to remove unnecessary obstacles to their ability to recover their costs from the parties that are liable for the contamination. At the same time, EPA believes it is important to establish a standard against which to measure cleanups that qualify for cost recovery under CERCLA, so that only CERCLA-quality cleanups are encouraged.

Id. at $46,8792-93$.

Failure to comply with the NCP does not create liability for the cleaning private party. It simply disallows recovery under CERCLA's liability scheme. Id. at 46,8796. Restitution for the plaintiff's expenses under the unjust enrichment theory may be possible under a state law claim. Id.

The court in Amland Properties Corp. v ALCOA, 711 F. Supp. 784 (D.N.J. 1989), stated that to be consistent with the NCP, a private party must either follow the specific provisions delineated in the NCP or prove to the court that one or more of the elements of the NCP were inappropriate given the circumstances. Id. at 799-800.

For a good recent discussion of these issues, see County Line Inv. Co. v Tinney, 933 F.2d 1508 (10th Cir. 1991) (barring recovery to a private party for failure to comply with the NCP as it existed when the plaintiff took investigatory and remedial actions).

27. CERCLA \$ 101(24), 42 U.S.C. \$ 9601(24), defines "remedy" or "remedial action" to be "those actions consistent with permanent remedy taken instead of or in addition to removal actions."

28. CERCLA \& 101(25), 42 U.S.C. \& 9601(25), defines “'respond' or 'response' [to mean] remove, removal, and remedial action; all such terms ... include enforcement activities related thereto."

29. This fund receives its monies from taxes on petroleum and chemical feedstocks, as well as from a general corporate environmental tax, and is intended to be a revolving fund whose sources are to be replenished when the government either settles with responsible parties or wins a judgment against a responsible party. See 42 U.S.C. \& 9611 (1988 \& Supp. II 1990); see also 26 U.S.C. 89507 (1988 \& Supp. II 1990) (Internal Revenue Code provision for the Hazardous Substance Superfund); 26 U.S.C. \$\$ 461112 (1988 \& Supp. II 1990) (tax on crude oil); 26 U.S.C. \$\$ 4661-62 (1988) (tax on chemical feedstocks); and 26 U.S.C. \& 59A (1988 \& Supp. II 1990) (general corporate environmental tax).

30. CERCLA \& 104(a)(1), 42 U.S.C. \& 9604(a)(1).

31. CERCLA \& 105, 42 U.S.C. \& 9605 (1988). The NPL is published as an appendix to the NCP. 40 C.F.R. 300, app. B (1991). Sites on the NPL are those that have been found by the EPA to present the greatest danger to human health and the environment. Each site is ranked according to several factors that reflect the extent of the toxicity, combustibility, explosivity, access to air and water channels, and proximity to human contact. The EPA utilizes what is referred to as the "Hazardous Waste Site Ranking System" to determine the relative priority for cleaning up a particular site. 40 C.F.R. Part 300, App. A (1982). For insight into and comments about how sites are selected for the NPL, see OFFICE OF TECHNOLOGY ASSESSMENT, COMING CLEAN: SUPERFUND PROBLEMS CAN BE SOLVED 85-136 (1989).

32. See generally Anne D. Weber, Note, Misery Loves Company: Spreading the Costs of CERCLA Cleanup, 42 VAND. L. REV. 1469, 1474-88 (1989). 
and several liability furthers the goal of quickly reimbursing Superfund, thus freeing the EPA to pursue other cleanup activities. ${ }^{33}$ Because a high priority of public suits is to replenish Superfund, and not to allocate applicable costs among private parties, proscription of caveat emptor as a defense is justified. Since private party actions do not involve governmental enforcement policy and utilization of Superfund monies, however, the same rationale does not apply.

Courts have recognized a private cause of action under CERCLA even though the legislative history provides no evidence of debate or discussion on the issue. ${ }^{34}$ The plain language of section $107(\mathrm{a})(4)(B)$ unequivocally allows "any other person" besides the government to recover "any other costs of response" necessarily incurred during a cleanup that was done in a manner that is "consistent with the [NCP]."35 While this allows the private party claim, courts have been left with no congressional guidance in determining which costs are "necessary" and therefore recoverable.

33. Dower, supra note 11 , at 175 .

Joint and several liability ensures that the government will not need to find every available defendant in order to recover its costs. See United States v. Dickerson, 640 F. Supp. 448, 450 (D. Mich. 1989); see also United States v. Conservation Chem. Co., 589 F. Supp. 59, 63 (W.D. Mo. 1984); United States v. Northeastern Pharmaceutical \& Chem. Co., 579 F. Supp. 823, 845 n.26 (W.D. Mo. 1984). The minimization of legal costs (and time spent on litigation) allows the government the liberty to pursue more actual cleanups.

One commentator has written that "the legislative history [of SARA] reflected that in replenishing the Superfund, Congress was aware that the EPA would not have adequate monetary and personnel resources to clean up all the hazardous waste sites that needed attention." Steven B. Russo, Note, Contribution Under CERCLA: Judicial Treatment After SARA, 14 COLUM. J. ENVTL. L. 267, 269 (1989) (citations omitted).

Another commentator has stated that

[t] he primary question is whether society as a whole will bear the costs of the cleanup or whether the industries that created the wastes will. Once Congress has decided that industry, and not society, shall pay for the cleanup, the next question is who in industry will pay. If we abide by the strict rules of causation, whereby individual firms pay only for those cleanup costs that are demonstrably theirs, then the responsibility for a substantial portion of the waste cleanup will still fall on society's shoulders. ... Thus to ensure that society as a whole pays as little as possible for cleanup costs, the EPA argues for, and the courts impose, joint and several liability.

White, supra note 8, at 911-13 (footnotes omitted).

34. See, e.g., Walls v. Waste Resource Corp., 761 F.2d 311, 318 n.6 (6th Cir. 1985); Dedham Water Co. v. Cumberland Farms Dairy, Inc., 805 F.2d 1074, 1078 (1st Cir. 1986); Pinole Point Properties, Inc. v. Bethlehem Steel Corp., 596 F. Supp. 283, 293 (N.D. Cal. 1984); County Line Inv. Co. v Tinney, 933 F.2d 1508, 1511 (10th Cir. 1991); see also Lewis M. Barr, CERCLA Made Simple: An Analysis of the Cases Under the Comprehensive Environmental Response, Compensation and Liability Act of 1980, 45 BUS. LAW. 923, 937-38 (1990); Jeffrey M. Gaba, Recovering Hazardous Waste Cleanup Costs: The Private Cause of Action Under CERCLA, 13 ECOL. L.Q. 181, 183 (1986).

35. 42 U.S.C. $89607(\mathrm{a})(4)(B)$.

36. One issue is whether preliminary costs, necessary to determining the scope of the problem but not done consistently with the NCP, are recoverable. One commentator believes that a broad reading of the phrase "necessary cost of response" is "consistent with the congressional intent to encourage private cleanup efforts." Gaba, supra note 34, at 215; see also Southland Corp. v. Ashland Oil, Inc., 696 F. Supp. 994, 999-1000 (D.N.J. 1988) ("[R]emedial investigations such as the one undertaken by Southland are consistently held to be within the scope of response costs."). However, some courts have ruled that preliminary assessments must comply with the NCP to be recoverable. See Tinney, 933 F.2d at 1511 (ruling that investigation and closing costs were not recoverable because they were not incurred consistently with the NCP); accord Amland Properties Corp. v. ALCOA, 711 F. Supp. 784, 790, 794 


\section{SARA and Contribution Rights: The Two-Phased Approach}

Prior to the Superfund Amendments and Reauthorization Act of 1986,37 CERCLA did not expressly provide for contribution among responsible parties held jointly and severally liable. Nonetheless, courts implied that the right of contribution was intended by the overall scheme of CERCLA or by the federal common law. ${ }^{38}$ SARA embodied express acceptance of the right of contribution among responsible parties. ${ }^{39}$ The goals of the new contribution section echoed the overall goals of SARA: to "encourage quicker, more equitable settlements, decrease litigation and thus facilitate cleanups." ${ }^{40}$ By allowing contribution suits, CERCLA facilitates settlement between the EPA and any potentially responsible party (often a "deep pocket"), who then may pursue contribution actions against other PRPs. ${ }^{41}$

SARA creates a two-phased approach to CERCLA liability: liability to the government by a party or parties, presumably a deep pocket, followed by contribution suits (with the government no longer involved in the litigation) against other PRPs. The nature of the first phase is retroactive, joint and several, strict liability. The nature of the second phase differs from the first in that it expressly considers equitable factors in the apportionment process.

The first phase quickly delivers the funds necessary to replenish Superfund into the hands of the EPA, which requires the funds to fulfill its obligation of remediating more sites. The second phase gives the party that funded the

(D.N.J. 1989). Part of the controversy is caused by CERCLA's definition of "response costs" which includes "the costs of investigating and remedying the effects of a release . . ." Tinney, 933 F.2d at 1512 n.7 (citing CERCLA § 101(23)-(25), 42 U.S.C. § 9601(23)-(25)). It should be noted that the definition does not require investigation to be done consistently with the NCP; parties and courts have interpreted the definition to be modified by the language of $\& 107(\mathrm{a})(4)(B)$ 's consistency clause.

37. Pub. L. No. 99-499, 100 Stat. 1613 (1986).

38. See, e.g., United States v. Chem-Dyne Corp., 572 F. Supp. 802, 805-08 (S.D. Ohio 1983); see also United States v New Castle County, 642 F. Supp. 1258, 1269 (D. Del. 1986); United States v Conservation Chem. Co., 619 F. Supp. 162, 228 (W.D. Mo. 1985).

39. CERCLA \& 113(f)(1), 42 U.S.C. $\$ 9613(\mathrm{f})(1)$ (1988), now provides as follows:

Any person may seek contribution from any other person who is liable or potentially liable under section 9607 (a) $[\$ 107(\mathrm{a})]$. . . during or following any civil action under section 9606 [\$106] of this title or under section 9607 (a) $[\$ 107(\mathrm{a})]$ of this title. ... In resolving contribution claims, the court may allocate response costs among liable parties using such equitable factors as the court determines are appropriate.

The legislative history of SARA states that the "uniform federal rule on joint and several liability [promulgated by the court in Chem-Dyne] is correct and should be followed. ... [N]othing in this bill is intended to change the application of the uniform federal rule of joint and several liability enunciated by the Chem-Dyne court." SUPERFUND AMENDMENTS AND REAUTHORIZATION ACT OF 1986, H.R. Rep. No. 253(I), 99th Cong., 2d Sess. 74 (1986), reprinted in 1986 U.S.C.C.A.N. 4, 2835, 2856.

40. H.R. Rep. No. 253(I), 99th Cong., 2d Sess. 59, reprinted in 1986 U.S.C.C.A.N. 4, 2835, 2841.

41. See generally Weber, supra note 32, at 1469; Russo, supra note 33 (discussing different forms of apportionment possible under CERCLA); see also, Lewis A. Kornhauser \& Richard L. Revesz, Apportioning Damages Among Potentially Insolvent Actors, 19 J. LEG. STUD. 617 (1990) (distinguishing between "legal contribution," that which allows the initially liable party to sue others only for their respective share of the contamination, and "equitable contribution," that which allocates to others their respective share of the contamination, plus their proportionate share of the costs of cleaning contamination caused by now insolvent contributors). 
cleanup "its day in court," by allowing it to sue other responsible parties. While the first phase acts as an expedited emergency action, the second phase acts more like a conventional suit. This is true because the second phase considers the relative positions of the parties. The second phase is also almost always more complex and time consuming.

While the advantage of the two-phased system is obvious-Superfund replenishment is expedited-as noted above, it is unnecessary in purely private party claims. Private PRPs have no obligation to clean other sites, and thus have no similar need to expedite replenishment of funds. ${ }^{42}$ CERCLA should allow courts trying private party cases to collapse the two phases when it would be feasible. Accordingly, the relative equitable positions of the parties in private claims need not be passed over in haste. Fairness and efficiency in private party cases can replace the "quick fix" of the government liability case.

CERCLA courts may implement equitable principles in a variety of ways. First, in determining the seller's liability, courts could interpret CERCLA to allow the use of the equitable factors that permeate the other aspects of CERCLA. Second, courts, recognizing the equitable jurisdiction that emanates from CERCLA's restitutionary nature, could exercise their inherent power as courts of equity by applying equitable principles. Third, courts could collapse the distinction between section 107 liability and section 113 contribution actions, applying the equitable principles of section 113 at the earlier stage. Finally, courts may apply caveat emptor by declaring the general liability of the seller, but equitably denying any recovery to the purchaser during the contribution phase. The purchaser under the last two options is brought into the contribution claim as the owner of the property. Certainly, in cases where there are many PRPs, the court may be aided by bifurcating the process. In situations where a current owner is suing only the former owner(s), however, the court could dismiss the issue of liability based on the equities between the two parties.

The next section analyzes the defense of caveat emptor and its equitable characteristics generally as a prelude to its treatment in CERCLA decisions.

\section{III}

\section{EQUITY AND CAVEAT EMPTOR}

The body of law termed "equity" has a rich and mythic history in this country. Equity, by definition, concerns itself with inherent fairness to individuals, even in the absence of a clear-cut policy established by the representative

42. Of course, all parties would prefer immediate reimbursement for all expenditures made on behalf of another. In all instances when the legal process is used, reimbursement will be delayed. Those who argue that cleanups will be avoided if a private party is required to wait through an entire proceeding involving the equities of the case do not consider the realities of the legal system. The threat of the government bringing a suit against the private party, which could require that party to seek contribution under $\S 113$ anyway, should be sufficient to induce the rational, risk-averse property owner to remediate. Likewise, cleaning a site at an earlier stage ensures that the problem will not become worse (and those affected by the contamination will be affected to a lesser degree). 
majority. Above all, equity concerns itself with the amorphous goal of "justice." Edward Re, expanding on Zechariah Chaffee, Jr.'s definition, described equity as

a way of looking at the administration of justice, the goal is to do justice in the particular case. It implies a liberating influence which mitigates the rigidity of formal rules. Its aim is to achieve an individualization of justice. In this sense, equity is that part of our legal heritage that has given the law an ethical dimension. In extolling virtues of candor and good faith, it reaffirms the moral element of a just society. ${ }^{43}$

Some commentators claim the principles of equity have an implicit position in our system of jurisprudence; they are principles understood by all judges, and need not be included in statutes because their nature makes them implicit in all formal law. ${ }^{44}$ This view emanates from the belief that there are absolute forms of just behavior and that judges are capable of knowing them. While the existence of "just behavior," in absolute terms, is by no means a settled concept, equity has been expounded upon by legal tradition. Equitable principles, derived from the English Chancery courts' decisions, have survived as reasonably welldefined maxims. ${ }^{45}$ Historically, the recognition of equitable defenses and remedies has always been at the discretion of a judge with equitable powers. ${ }^{46}$ Justice Story wrote, " $[\mathrm{T}]$ he exercise of ... equity jurisprudence ... is not a matter of right in either party; but a matter of discretion in the Court . . . which governs itself, as far as it may, by general rules and principles . . . according to the circumstances of each particular case . . .".47

Modern environmental law has proved a difficult area in which to determine the proper role of a court's equitable discretion. Federal environmental law appears to emanate from both traditionally legal and traditionally equitable powers. At the same time, many federal statutes include provisions allowing courts to use the discretionary equitable power of injunction. ${ }^{48}$

Real property transactions, which, until recently, have not been a traditional subject of complex statutes, have historically been subject to equitable considerations. $^{49}$ For instance, nondisclosure of potential hazardous waste

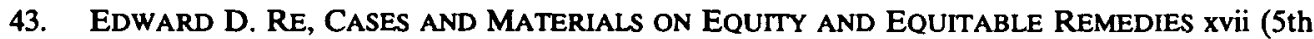
ed. 1975).

44. See, e.g., id. at 221 n.3 (quoting Aristotle's Nicomachean Ethics).

45. See id. at 11-14. Re lists several of these maxims, among them: "He who seeks in equity must do equity"; "He who comes in equity must come with clean hands"; "Equity aids the vigilant, not those who slumber on their rights"; "Equity follows the law"; "Equity regards substance rather than form"; "Equity imputes an intent to fulfill an obligation"; "Between equal equities the law will prevail"; "Between equal equities the first in order of time shall prevail"; "Equity abhors a forfeiture"; and "Equity will not aid a volunteer." 776.

46. DAN B. DOBBS, HANDBOOK ON THE LAW OF REMEDIES 52-55 (1973); Re, supra note 43, at

47. JOSEPH STORY, 2 EQUITY JURISPRUDENCE AS ADMINISTERED IN ENGLAND AND AMERICA $\$ 1026$ (14th ed. 1918).

48. See generally Daniel A. Farber, Equitable Discretion, Legal Duties, and Environmental Injunctions, 45 U. PITT. L. REV. 513 (1984) (concluding that the focus of courts applying environmental statutes should be on congressional intent and not on "the equity mystique").

49. "With respect to contracts for the sale of land, the role of equity has long been paramount." ROBERT S. THOMPSON \& JOHN A. SEBERT, JR., REMEDIES: DAMAGES, EQUITY AND RESTITUTION 855 (2d ed. 1989). 
liability to a prospective buyer may be a cause for relief for the buyer on the contract; ${ }^{50}$ the same is not true, however, when the defects of the property are known or are sufficiently obvious to have been known to the purchaser. ${ }^{51}$ One would assume, if the principles of equity are working fully, that compliance with a system of mandatory disclosure of environmental defects would allow one to assert caveat emptor against a purchaser. "Caveat emptor," which means "let the buyer beware," has been utilized for ages in real property transactions, especially where material defects to the property are readily observable. ${ }^{52}$ As a defense, caveat emptor completely disallows any recovery to a plaintiff who has had ample opportunity to examine the item under consideration. Allowing the defense of caveat emptor creates an incentive for the purchaser to inspect closely the good being purchased. This incentive is desirable from an equity standpoint because it promotes a true "meeting of the minds" in transactions, placing the purchaser and seller on equal terms.

The current concern about hazardous waste, which is almost always unobservable without inspection, has alerted sophisticated purchasers to the possibility of its presence. This is especially true if the purchaser is aware that the seller, or any other previous owner, utilized, stored, or transported hazardous material. Knowing this, the purchaser should take the necessary steps to determine the extent of the contamination by inquiring into such matters with the seller, and by conducting environmental inspections or auditing processes. The prospective purchaser should then set a price that reflects the value of the land, given any environmental concerns. ${ }^{53}$ As stated above, this creates a parity

50. See John Willard, A Treatise on Equity JuRisprudence 177 (New York, Banks \& brothers 1875). In contract terms, material nondisclosure could be considered fraudulent inducement or could allow the purchaser to void the contract on the basis of mistake. Farnsworth discusses the paradigmatic case where the current homeowner knows his house is infested with termites but does not inform the prospective buyer:

Courts have been increasingly willing to hold that failure to disclose this fact amounts to an assertion that it is not riddled with termites. The Restatement Second recognizes this trend by generally making a party's nondisclosure of a fact equivalent to an assertion that the fact does not exist if "he knows that disclosure of the fact would correct a mistake of the other party as to the basic assumption on which the party is making the contract."

E. AlLAN FARNSWORTH, CONTRACTS 240 (1982).

Courts have generally found no duty of the purchaser to inform the seller of facets of the seller's land that make it more valuable than the seller believes. Id. at 240-41 (citing Caples v. Steel, 7 Or. 491 (1879); Neill v. Shamburg, 27 A. 992 (1893); Harris v. Tyson, 24 Pa. 347 (1855); and Blair v. National Sec. Ins. Co., 126 F.2d 955, 958 (3rd Cir. 1942)).

51. Willard wrote, "When the defects are patent, and such as might have been discovered by a vigilant man, or when the contract was entered into with full knowledge of them, equity will not afford relief." WILLARD, supra note 50, at 181.

52. "Caveat emptor ... summarizes the rule that a purchaser must examine, judge, and test for himself." BLACK's LAW DICTIONARY 222 (6th ed. 1990).

"Caveat Emptor [is] a maxim of common law expressing the rule that the buyer purchases at his peril .... The maxim is applicable to sales of real estate in respect of conditions of the premises open to observation." BaLlentine's LAW Dictionary 183 (3d ed. 1969).

53. With all the concern for cleaning up hazardous waste sites in recent years, one may correctly argue that taking away the purchaser's right to sue the seller for cleanup expenses would greatly reduce the amount of real property transactions in the country. This is not undesirable from a market perspec- 
of knowledge between the two parties. Although the price of the property will be diminished initially, resulting in fewer willing sellers, the transactions that do occur will be entered into by parties that have a full understanding of the value of the property.

The argument is not that caveat emptor should always be used. As stated above, it should be available to the judge if necessary to avoid inequitable results, such as double recovery. Although CERCLA provides courts with the ability to consider the relative equities of a case, the CERCLA cases reviewed in part VI show that courts are currently uncertain about the place of equity in determining liability. The next part of this article discusses the effect of CERCLA on real property transactions. A full understanding of CERCLA's impact is necessary to illustrate caveat emptor's usefulness.

\section{IV}

\section{The Effect of CERCla on Commercial Property Transactions}

Modern real estate transactions have begun to adjust to the policy of internalizing the external costs of hazardous waste cleanups. CERCLA increases the likelihood that these external costs to society will ultimately be shifted to the parties. $^{54}$ Parties involved in real estate transactions are now discussing environmental costs at the bargaining table. Many recent real estate transaction guides discuss the necessity of accurate environmental appraisals. ${ }^{55}$ Test pits, soil samples, permit reviews, management and employee interviews, and other environmental auditing procedures are often employed prior to a sale. ${ }^{56}$

The heightened awareness of CERCLA among commercial real estate purchasers and sellers is understandable. A 1988 survey conducted by the Roper Organization indicated that more than sixty percent of those polled viewed the problem of hazardous waste as very serious. ${ }^{57}$ Indeed, the problem has been followed by nearly all media sources that cover local issues. It is reasonable to assume that commercial real estate purchasers are on notice of the issue. Further, when attempting to obtain permits from local regulatory agencies,

tive, however. As discussed in Part VI, infra, society currently is involved in too many contaminated property transactions due to misunderstanding the true value of the property.

54. There is no guarantee, however, that even a clearly contaminated site will be an object of enforcement by the EPA. The EPA is authorized to bring restitutionary actions against parties for remedial actions only if the site is on the National Priority List, 42 U.S.C. $\$ 9604$, if the site is in need of response actions due to a release or threatened release, 42 U.S.C. $\$ 9606$, or if the EPA issues a unilateral cleanup order pursuant to 42 U.S.C. $\$ 9606$. Similarly, there is no guarantee that a site will be cleaned by a private party even though a party may clean and sue for restitution under 42 U.S.C. $\$$ 9607(a)(4)(B).

55. See, e.g., PLI HANDBOOK, supra note 18; A.L.I.-A.B.A. MATERIALs, supra note 18; JoEL S. MOSKOWITZ, ENVIRONMENTAL LIABILITY AND REAL PROPERTY TRANSACTIONS: LAW AND PRACTICE (1989 \& Supp. 1992).

56. For environmental analysis techniques and examples, see, e.g., ICC GuIDE TO EFFECTIVE ENVIRONMENTAL AUDITING (1991); THOMAS N. TRUITT ET AL., ENVIRONMENTAL AUDIT HANDBOOK: Basic Principles of EnVIronmental Compliance Auditing (2d ed. 1983); and William M. MARSh, ENVIRONMENTAL ANALYSIS FOR LAND USE AND SITE PLANNING (1978).

57. Cited in Dower, supra note 11, at 151-52. 
developers should be aware of the issues that local officials face when dealing with local constituencies. Hazardous waste contamination, while national in interest, hits hardest at the local level, where drinking water is contaminated, soil becomes unusable, and people's health is harmed. As local permit-granting agencies increasingly are held accountable, they are beginning to require cleanup plans in advance of transactions. ${ }^{58}$

The vast scope of contamination also serves to heighten the public's awareness of hazardous waste contamination. According to a recent congressional study, 250 million metric tons of hazardous waste are produced each year by some 650,000 generators. ${ }^{59}$ Ninety-five percent of the hazardous waste generated is disposed of on-site, further emphasizing the need for purchasers to inquire extensively into the past use of the land.$^{60}$ At the time of CERCLA's enactment, it was estimated that 30,000 to 50,000 sites nationwide contained hazardous waste, of which 1200 to 2000 presented serious health risks. ${ }^{61}$ Today government agencies disagree about the actual number of hazardous sites: the EPA lists 27,000 abandoned waste sites, the General Accounting Office reports that between 130,000 to 425,000 sites need cleanup, and the Office of Technology Assessment estimates at least 600,000 sites pose a threat to human health and the environment. ${ }^{62}$

While no regulations define the scope of a purchaser's diligence in investigating commercial property prior to a transaction, many of the guides available to developers, lawyers, and lenders discuss the potential liability under CERCLA if the EPA demands a cleanup after the transaction has occurred. ${ }^{63}$ There are also no regulations promulgated under CERCLA that require the purchaser to disclose to the seller the details of any environmental assessment the purchaser may have undertaken on his or her own behalf prior to the closing. ${ }^{64}$ Still, a purchaser who claims that he or she was unaware of any contamination on the site prior to purchasing it must have been diligent in his or her pre-purchase inquiry to assert the innocent owner defense of CERCLA section 107(b)(3) in a suit for cleanup costs brought by the EPA. ${ }^{65}$ Knowledge

58. See infra notes 67-69 and accompanying text.

59. Of the 650,000 generators, only two percent contribute $95 \%$ of the wastes. J. E. MCCARTHY AND M. E. ANTHONY REISCH, CONGRESSIONAL RESEARCH SERVICE, HAZARDOUS WASTE FACT BOOK, 87-56 ENR (1987), cited in Dower, supra note 11, at 154-55.

60. Id.

61. 1 CERCLA LEG. HIST., supra note 7, at 91.

62. Dower, supra note 11, at 157-58. At least 1087 federal facilities are thought to need cleanup as well. Id. at 159.

63. See infra note 67.

64. The opposite is not true, however. A variety of liability situations exist for the seller for nondisclosure of known environmental contamination. See note 50 and accompanying text.

65. Section $107(b)(3)$ of CERCLA states that there shall be no liability if the party can prove by a preponderance that the contamination was caused solely by

an act or omission of a third party other than an employee or agent of the defendant, or than one whose act or omission occurs in connection with a contractual relationship, existing directly or indirectly, with the defendant ... if the defendant establishes by a preponderance of the evidence that (a) he exercised 
of potential CERCLA liability and the requirements of the innocent purchaser defense are incentives for investigation by the purchaser. Yet, without the defense of caveat emptor, no such incentives encourage disclosure by the seller. Although the common law indicates that there is no general duty to disclose known hazards, ${ }^{66}$ CERCLA itself is facially silent on the issue.

Perhaps because of this silence, some states regulate the conditions that must be met before a transfer can occur; most simply require disclosure, recording of environmental conditions, or both. ${ }^{67}$ New Jersey's Environmental Cleanup Responsibility $\mathrm{Act}^{68}$ is "recognized as creating the most potent weapon for environmental enforcement of this kind." 69 It mandates that no industrial property is to be transferred until the New Jersey Department of Environmental Protection is satisfied that the property is free of contamination.

Even absent state regulation, the principles of caveat emptor-seller disclosure and purchaser inspection-have been incorporated in real property transactions in clever ways despite some courts' proscription of it as a complete defense. One such incorporation is the use of indemnification clauses ${ }^{70}$ between $^{-}$

due care with respect to the hazardous substance concerned, taking into consideration the characteristics of such hazardous substance, in light of all relevant facts and circumstances, and (b) he took precautions against foreseeable acts or omissions of any such third party and the consequence that could foreseeably result from such acts or omissions.

42 U.S.C. $\$ 9607$ (b)(3). The purchaser/new owner will be considered to be in a contractual relationship with the seller/old owner, by virtue of the sales agreement, if the purchaser knew of the contamination, 42 U.S.C. $\$ 9601(35)(A)$, or if he or she did not make adequate inquiry into previous uses at the time of the transaction, 42 U.S.C. $\$ 9607(35)(B)$. This will invalidate the purchaser's ability to defend against liability should the purchaser be sued.

66. See supra note 51.

67. The Illinois Responsible Property Transfer Act, Pub. Act 85-1228, requires that the seller give to the purchaser an environmental disclosure document that, in turn, requires the seller to answer a series of questions related to on-site activities. The Act requires the document to be given to the purchaser no later than 30 days before the transfer. The Act also requires the document to be recorded. ILL. ANN. STAT. ch. 30, para. 901 (Smith-Hurd Supp. 1992).

Massachusetts law requires any discharge, spill, or hazardous waste disposal to be recorded in the registry of deeds prior to the conveyance of property. MASS. GEN. LAWS ANN. ch. 21C, $\$ 7$ (West 1979 \& Supp. 1992).

Minnesota requires an affidavit to be filed with the recording office before the conveyance of any property that the owner knows or should have known was used as a hazardous waste disposal facility. MinN. STAT. ANN. § 115B.16 (West 1987 \& Supp. 1992).

Pennsylvania requires the seller to acknowledge, in the description portion of the deed, the elements of the hazardous waste disposal that is occurring or has occurred. The Pennsylvania Solid Waste Management Act, 35 PA. Cons. STAT. ANN. $\$ 6018.405$ (Supp. 1992). See also W. VA. CODE $\S 20-5 E-20$ (1989). These statutes are briefly described in Donald W. Stever, ECRA and Other Restrictions on the Transfer of Hazardous Waste Sites, reprinted in PLI HANDBOOK, supra note 17, at 166-69.

68. N.J. STAT. ANN. $\$ 13: 1 \mathrm{k}-6$ to -35 (West 1991).

69. Stever, supra note 67 , at 170 .

70. See 42 U.S.C. $\$ 9607(\mathrm{e})$. One case that dealt with indemnification for private party response costs under CERCLA $\S 107$ was Emhart Industries, Inc. v. Duracell International, Inc., 665 F. Supp. 549 (M.D. Tenn. 1987). In Emhart, the plaintiff, Emhart Industries, bought the Mallory Components Group from defendant Duracell, a subsidiary of Dart Industries, Inc. During negotiations, plaintiff learned of polychlorinated biphenyl, or PCB, contamination on the site of one the manufacturing plants considered for purchase. The parties bargained for and accepted intricate contractual provisions that required the defendants to remove the PCB contamination and to indemnify the plaintiffs on all claims, obligations, 
sellers and purchasers. ${ }^{71}$ Courts have held that contracts to indemnify sellers against CERCLA liability must do so specifically. ${ }^{72}$ As indicated in Part VI(B), indemnification clauses function to incorporate the principles of caveat emptor expressly into contracts.

CERCLA liability, as with liability under most major legal instruments, has transformed the market in which it operates. The next part of this article argues that allowing the equitable defense of caveat emptor will result not only in greater fairness to the parties, but also in greater market efficiency.

\section{V}

\section{Removing THE CONTAMinated Property MARKet Distortion}

The primary goal of welfare economics is to determine whether any given market allocates its scarce resources efficiently in relation to the personal wants of the members of the relevant society. ${ }^{73}$ For a market to allocate resources efficiently, it is necessary that "all participants in the market are fully informed as to the quantitative and qualitative characteristics of goods and services and the terms of exchange."74 In the words of famed welfare economist A.C. Pigou,

and attorneys' fees arising out of “[a]ny obligation, liability, loss, damage or expense ... pertaining to health, safety or environmental protection and arising out of any act or omission by Seller." 665 F. Supp. at 555. The court upheld the agreement, and held the defendant liable for the cleanup (except that portion that was found to be attributed to plaintiff's activities). Id. at 574.

The seller's indemnification and warranty involved in Quadion Corp. v. Mache, 738 F. Supp. 270 (N.D. Ill. 1990) claimed that the property had no "liabilities . . known or unknown" and that the seller agreed to indemnify the purchaser against "any loss, damage or expense ... suffered as a result of any inaccuracy in or any breach of any of the representations . . . made by Defendant." Id. at 276-77. The defendant moved to dismiss liability on the instrument based on the fact that the defendant gave the warranty before the passage of CERCLA and was thus not aware of CERCLA's potential for inclusion under the terms of the agreement. The court denied the motion to dismiss, citing the fact that plaintiff's interpretation of the clause to include all possible future liability was not "an "impossible' one." Id. at 277.

71. These agreements may not be as socially desirable as they seem, however, because the buyer who achieves indemnification against liability for contamination does not have an automatic claim of restitution against the seller for cleanups that it undertakes of its own accord. Rather, the buyer is protected against loss when sued. The buyer therefore has incentive not to incur the expenses of a voluntary cleanup. A cleanup is more apt to occur if the buyer bargains the price down to reflect the future costs of its cleanup plan.

72. See, e.g., Boeing Co. v. Aetna Casualty \& Sur. Co., 784 P.2d 507, 516 (Wash. 1990); Southland Corp. v. Ashland Oil, Inc., 696 F. Supp. 994, 1000-01 (D.N.J. 1988) (discussed in Part VI.B, infra).

73. Allen V. KNEESE, ECONOMICS AND THE ENVIRONMENT 18-19 (1977). See also JOSEPH J. Seneca \& Michael K. TAUSSIG, ENVIRONMENTAL ECONOMICs 24 (4th ed. 1984) ("Social efficiency is not measured by aggregating physical quantities of goods and services . . . but rather by somehow aggregating the subjective values placed on different goods and services by individual consumer units."); EDWIN S. MILls, THE ECONOMICS of ENVIRONMENTAL QUALITY 68 (1978) ("The value judgment almost always used by economists is that an economic system's performance is to be judged by its ability to satisfy the needs and wants of people as they perceive them."); PAUL A. SAMUELSON, ECONOMICS 591 (11th ed. 1980); EDWIN MANSFIELD, MICROECONOMICS: THEORY AND APPLICATIONS $458-59$ (5th ed. 1985).

74. KNEESE, supra note 73, at 19. See also White, supra note 8, at 915 ("The market pricing mechanism tends to reflect both the degree of the consumers' desire for the product and the extent of society's resources used to produce it. If a commodity is very costly to produce, then its price should 
[a] flowing stream of resources is continually coming into being and struggling, so far as unavoidable costs of movement allow of this, to distribute itself away from points of relatively low returns towards points of relatively high returns. Success in this struggle is interfered with by imperfect knowledge on the part of those in whose hands the power to direct the various branches of the stream resides. ${ }^{75}$

Society, by allocating resources in one market incorrectly, loses the opportunity to use them in another; “[e]fficient resource allocation means that more of one commodity can be produced only by reducing the output of another commodity." 76 Although perceived short term efficiency may initially result, lack of full information on the part of the choice making consumer will result in resource allocation that is divergent from the true desires of the consuming public. ${ }^{n}$ This divergence creates an "external diseconomy" or "market distortion," so called because the market over or under buys based on an incorrect accounting of true costs. ${ }^{78}$

This distortion is exemplified by the many sales transactions of hazardous waste contaminated properties in which the existence of the waste was unknown to at least one of the parties. In making economic decisions, parties have failed to consider the hidden costs of future cleanup. Due to this failure, parties often underestimate the true cost of the transaction and ultimately engage in more than the optimal number of transactions. ${ }^{79}$

To assess the true costs of an activity to society, an economist must consider not only direct and transaction costs, ${ }^{80}$ but also externalities. Generally, externalities are costs that are allocated to society but are not considered by a firm during production. ${ }^{81}$ A firm engaged in production, if allowed to ignore the environmental effects of production, will likely produce its individual optimal level of output while surpassing the level of output optimal to society. ${ }^{82}$ This pattern of production ultimately results in inefficient allocation of society's resources. In order to optimize societal allocation of resources, a government may act to correct the market distortion. By assigning liability for this

reflect that cost, to ensure that the consumers' desire (which is reflected in the price they are willing to pay) is sufficiently high to warrant the production of such an expensive item.").

75. A. C. Pigou, The ECONOMICS OF Welfare 149 (4th ed. 1932).

76. THOMAS M. CARROLL, MICROECONOMIC THEORY, CONCEPTS AND APPLICATIONS 638 (1983).

77. SAMUELSON, supra note 73, at 449, 743-44; MANSFIELD, supra note 73, at 496.

78. See White, supra note 8, at 916-17.

79. MANSFIELD, supra note 73, at 476. This article assumes that this failure will have no effect on the overall amount of property that is remediated.

80. Transaction costs are those costs that the parties incur to facilitate the deal but are not considered costs of production, manufacture, or of substantive business. See MANSFIELD, supra note 73, at 264-66; RichaRd G. LiPSEY, PETER O. STEINER \& DOUGlas D. PURVIS, ECONOMICS 438 (7th ed. 1984); CARROLL, supra note 76, at 309-12.

81. SENECA \& TAUSSIG, supra note 73, at 26-39; SAMUELSON, supra note 73, at 743-47; MANSFIELD, supra note 73, at 495-96; MILLS, supra note 73, at 78-83; CARROLL, supra note 76, at 640. See also DANIEL ORR, PROPERTY, MARKETS, AND GOVERNMENT INTERVENTION 285-311 (1976).

82. MANSFIELD, supra note 73, at 499 ("Left to its own devices, the industry . . . will not reduce its pollution level [to the optimal amount], because it does not pay all of the social costs of its pollution.") See also SAMUELSON, supra note 73, at 449-50. 
externality to the responsible party, the government internalizes the externality. ${ }^{83}$

In discussing several cases in which it is most efficient for the government to tax a behavior that creates an externality, Pigou cites the example of intoxicating liquors. ${ }^{84}$ The government, he says, ought to tax (set the price above the cost to produce the good plus a reasonable profit) alcoholic beverages to pay for the increased need for police and prisons that accompanies increased consumption of alcohol. Like hazardous waste producers, producers of alcohol would not, in the absence of such a tax, account for the added social cost when determining what quantity of the good to produce. Not only will the tax revenues provide for the needed government service (whether police, prisons, or hazardous waste cleanups), but they will also create market pressures that will force the producer and the consumer to assess the social cost of the item accurately. ${ }^{85}$

This type of government imposed internalization has affected the market for commercial property sales. The effect of internalization on the commercial real estate market is measured by changes in the number of transactions, rather than in the amount of production. Prior to the development of environmental liability laws that held the causal agent of pollution externalities responsible, the market for commercial real estate had not internally adjusted to accommodate the pollution externality. The price asked by sellers in the market was, therefore, lower than the true equilibrium price, leading to more property transactions than would have occurred at the true equilibrium output level. ${ }^{86}$ Because these

83. CARRoll, supra note 76 , at 640 . See supra text accompanying notes $3-4$. Nobel laureate Ronald Coase has put forward a model that illustrates how externalities may be internalized by the perfectly competitive market economy without government regulation. If transaction costs are minimal, the party that desires less production by the polluter (those harmed by the pollution) will compensate the producer to produce less. The first party will continue to compensate the producer until its marginal benefit for the reduction of production is outweighed by the marginal benefit of the producer to produce the next unit. In other words, at some point, the first party will not be willing to pay the producer more than what she could get at market to produce the next unit. This is the optimal welfare level for society, according to Coase, because the marginal benefits of production are equal to the marginal benefits of non-production. Ronald H. Coase, The Problem of Social Cost, 3 J. L. \& ECON. 1 (1960). While the importance of this theory cannot be overstated, for externalities that involve all members of a community, such as hazardous wastes, transaction costs will serve to make the Coase theory irrelevant. See MANSFIELD, supra note 73, at 503.

84. PIGOU, supra note 75 , at 186.

85. Id.

86. The concepts of equilibrium price and quantity, while difficult to define tersely, have been described by Mansfield as follows:

Let us define the consumer's equilibrium behavior as a course of action that will not be changed by him or her in favor of some other course of action, if the consumer's money income, tastes, and the prices he or she faces remain the same. Then the consumer's equilibrium behavior will be to choose the market basket that maximizes his or her utility.

MANSFIELD, supra note 73, at 54. Samuelson describes the concepts in this manner:

The equilibrium price[:] the only price that can last, in that at which the amount willingly supplied and the amount willingly demanded are equal. Competitive equilibrium must be at the intersection point of supply and demand curves. 
excess property sales proved to be more expensive than originally believed, the purchasers had effectively purchased more than they would have wanted were they possessed of full information, creating a market distortion. As a byproduct of CERCLA, remediation costs are accounted for before they are incurred, removing this distortion.

A system of disclosure from the seller to the purchaser of all known environmental defects, followed by diligent inspection by the purchaser, will result in a transaction with full information. By adding the additional cost of cleanup expenses into the body of knowledge held by the parties in a real property transaction, the market for real property will eliminate the current distortion. Some investors will avoid the real property market due to its increased costs, and place their resources in other markets better reflecting their true desires, raising the overall welfare of society. Applying the principles of caveat emptor to the market for real property transactions thus makes sense economically, as well as equitably.

\section{VI \\ COURT INTERPRETATIONS OF CERCLA AND EQUITABLE DEFENSES}

Possibly due to the haste-created ambiguity with which CERCLA was written, the facial proscription of nonenumerated (that is, equitable) defenses to liability in section 107 has been subject to incongruous judicial interpretation. In general, courts follow one of two extreme approaches. The courts that follow the first approach believe that section 107's proscription is absolute, excluding not only possible legal defenses, but also equitable defenses, ensuring liability for all in the causal chain. Among the courts that utilize this approach, some allow caveat emptor and other equitable defenses only in the contribution phase. The second approach argues that the equitable nature of CERCLA requires that traditional equitable defenses be available to courts of equity. Some courts adhering to this approach reason that courts of equity maintain this status unless equitable remedies are expressly disallowed. Others hold that CERCLA confers general equitable powers onto the court while specifically providing for legal remedies and defenses in other sections. Each of these approaches is discussed in turn.

\section{A. Cases Disallowing Equitable Defenses to CERCLA Liability}

The leading case espousing the first approach considered whether a seller can assert caveat emptor against a sophisticated commercial purchaser. In Smith

\section{SAMUELSON, supra note 73 , at 57.}

The use of the term "true" to modify the equilibrium output and price level indicates that the parties' subjective knowledge of the costs differs from the real cost that will be incurred by them. This article assumes that it is possible to determine the parties' equilibrium levels even if they are unaware of the true costs. 
Land and Improvement Corp. v. Celotex Corp. ${ }^{87}$ the purchaser sought contribution from the seller's successor for expenses incurred in connection with a cleanup of on-site wastes, including asbestos. ${ }^{88}$ The court stated that

the plaintiff's predecessor was a sophisticated company which had inspected the land on five occasions, known of its past use, and admitted that the pile of waste was a "negative" factor in the decision to purchase the land. Despite the plaintiff's assertion that it lacked knowledge about the hazards of asbestos, the [district] court concluded that the "price plaintiff paid for the land refiected the possibility of environmental risks."

The court of appeals, however, stated that despite the purchaser's awareness of the hazard and the subsequent mark down in price, caveat emptor was not available as a defense in the liability phase of a CERCLA action. ${ }^{90}$ The court relied on the language ${ }^{91}$ of section $107(a)$, which states that liability shall attach to certain parties for certain costs "subject only to the defenses set forth in subsection (b) ...." The defenses of subsection (b) are policy decisions that reflect issues of causation such as the intervention of an act of God, an act of war, or of an act entirely caused by an unrelated third party that was uncontrollable by the party, while the party took reasonable precautions against the action. ${ }^{92}$

While recognizing that certain equitable principles coexisted with the three enumerated defenses to liability, the court of appeals first reasoned that caveat emptor would create a disincentive for private parties to clean their sites quickly. Private cleanups would be unlikely, the court stated, as new owners (purchasers) would await a legal ruling of apportionment before actually cleaning the sites. ${ }^{93}$ This policy justification is insufficient, however, because, as the court itself mentioned earlier in its decision, the EPA can order parties to clean the sites immediately under section $106 .{ }^{94}$

Despite citing a segment of the legislative history that states that equitable considerations are to be considered alongside the three express defenses of the

87. 851 F.2d 86 (3rd Cir. 1988).

88. As occurs in many private party cleanups, EPA here warned Smith Land that if it did not remediate the site, the federal government would do so. Id. at 87; see also CERCLA \& 106, 42 U.S.C. $\S 9606$.

89. Smith Land, 851 F.2d at 88.

90. Id. at 90 . The court did say that the principles of caveat emptor may be available in apportioning costs in a contribution proceeding. CERCLA itself mandates that courts, during the contribution proceedings, allocate expenses "among liable parties using such equitable factors as the court determines are appropriate." CERCLA \& 113(f)(1), 42 U.S.C. $\$ 9613(f)(1)$.

91. Like the court in Smith Land, the court in United States v. Stringfellow, 661 F. Supp. 1053, 1062 (C.D. Cal. 1987), found CERCLA $\$ 107$ (a), 42 U.S.C. $\$ 9607$, to deny other defenses based on the "plain meaning" of the language used.

92. CERCLA $\$ 107(b), 42$ U.S.C. $\S 9607$ (b).

93. Smith Land, 851 F.2d at 90.

94. One commentator notes that private parties have a strong incentive to clean without the EPA's involvement because once the EPA names a party as a PRP, it is likely that the party will be initially (jointly and severally) liable for all of the EPA's costs-even those allocated to parties that it cannot find. An initially liable PRP can recover only the shares positively attributed to other parties it sues for contribution. As such, the costs attributed to unknown parties go unreimbursed. Yvette Gonzales, Note, The Best Equitable Defense is a Good Offense, 29 NAT. RES. J. 849, 858 (1989). 
liability section (section 107$),{ }^{95}$ the court rejected equitable defenses to liability, such as caveat emptor and "unclean hands," because, paradoxically, they would be inequitable in the context of environmental cleanups. Rather than preclude any recovery by the purchaser as in caveat emptor, the court concluded that it was equitable at the contribution phase to reduce the seller's financial burden by the discount that was bargained for in light of the potential for environmental problems.

The Smith Land court feared that, if caveat emptor and "unclean hands" were allowed as defenses to liability, a purchaser might be liable for a much greater share of the cleanup cost than is equitable. This reasoning fails to consider four aspects of real property transactions that stand to justify caveat emptor as a complete defense: (1) only the purchaser (the new owner) will benefit from a clean site when the property is reassessed or sold; (2) an important aspect of a free market is that the parties to a transaction may value the risks however they choose; (3) the knowledge that it will not be able to recover from the seller will force the purchaser to evaluate the environmental status of the land thoroughly before the transaction to ensure that the price reflects the true costs of the property; ${ }^{96}$ and (4) caveat emptor and unclean hands can be defenses for the seller only if the seller has acted reasonably and honestly. ${ }^{97}$ In the absence of a statute requiring disclosure of hazardous waste, caveat emptor, as a complete defense for private party property sellers, may be helpful in mandating such disclosure. To take advantage of the defense, the seller would be required to disclose all known hazardous waste information to the purchaser before closing the transaction. Certainly, sellers would be attracted to a system where their potential liability is limited from the time the transaction is concluded.

In United States $v$ Kramer, ${ }^{98}$ another case following the first approach, the court concluded that "consideration of 'equitable factors' only comes into play during the contribution phase and does not affect the liability of each defendant in a section 107 action." Kramer, unlike Smith Land, was brought by the government, rather than a private plaintiff. The government sought to strike

95. H.R. REP. No. 253(I), 99th Cong., 1st Sess. 1, 80 (1985), reprinted in 1986 U.S.C.C.A.N. 2835, 2862 ("Although the only defenses to liability remain those set forth in Section [107(b)], courts are to resolve such claims on a case-by-case basis, taking into account relevant equitable considerations.”).

96. The court in Smith Land recognized "[ $t$ ]he duty of inspection implicit in caveat emptor ....." Smith Land, 851 F.2d at 90 n.1. It felt that this was embodied in the text of 42 U.S.C. $\S 9601(35)$ (B), where a landowner is relieved from "initial liability on proof that after 'all appropriate inquiry ... consistent with good commercial or customary practice' the owner had no reason to know of the presence of a hazardous substance." Id. This is not an apposite statement, however, as $\S 9601(35)(\mathrm{B})$ concerns an owner of land attempting to avoid liability as an owner/operator, as that term is used in $\S$ 9607(a). Caveat emptor attempts to apportion liability to the correct party among more than one PRP. The act of inspection, under caveat emptor, is not utilized by the landowner to avoid liability; it is done by the land purchaser to insure that all costs, however hidden, are accounted for in the purchase price.

97. This is inherent in the maxims that "He who seeks equity must do equity" and "He who comes in equity must come with clean hands." See supra note 45.

98. 757 F. Supp. 397 (D.N.J. 1991).

99. Id. at 413 . 
approximately 200 of some 300 affirmative defenses not expressly listed in section 107(b), set forth in the answers of sixteen of the twenty-nine existing defendants named as PRPs at the Helen Kramer Landfill in Mantua, New Jersey. ${ }^{100}$

As in Smith Land, the court in Kramer barred the application of equitable principles during the liability phase but considered application possible during the contribution phase. ${ }^{101}$ The defendants protested that it was irrelevant to the disposition of the case whether they asserted their equitable defense during the former or the latter proceeding. ${ }^{102}$ Stating that all parties are jointly and severally liable if the harm is indivisible, the court found that affirmative defenses, other than those in section 107(b), are appropriate only in the contribution phase, and then only if the harm at the site is divisible.

The defendants, using a novel approach, attempted to collapse the distinction between the section 107 liability phase and the section 113 contribution phase by stating that they intended to name the government as a contributor; thus the defendants claimed that the action was really one of contribution between the government and the defendants. As this would ultimately be a section 113 contribution claim, the defendants argued, equitable defenses to liability should be allowed. ${ }^{103}$ The court disagreed with this reasoning, stating that CERCLA requires the government to bring actions against defendant PRPs who will be jointly and severally liable, leaving to the PRPs the right of contribution against third-party defendants, who will be only severally liable. The government, said the court, can be brought in only during the contribution phase, and can be held to pay only those costs directly related to its share of the contamination. ${ }^{104}$ Thus, under Kramer, the government is not responsible for paying the portion of the costs attributable to parties that were not solvent or locatable at the time of the litigation. This is consistent with the policy concerns of preserving government funds for other cleanups where no PRP has been found and for

100. Id. at 404. Aside from equitable defenses, the defendants also listed constitutional defenses that could not be preempted by CERCLA, defenses under other sections of CERCLA, and the Administrative Procedure Act, 5 U.S.C. \$\$ 551-706 (1988), which they claimed should be allowed under CERCLA $\$ 107$ as necessary to the implementation of CERCLA as a whole, and defenses arising against the government itself as a generator of hazardous substances. Kramer, 757 F. Supp. at 404-05.

101. Id. at $412-13$.

102. Id. at 405 . In support of the defendants, the ability of the PRPs to defend on liability before defending on contribution will have a great effect on the transaction costs a defendant incurs, as it may effect the disposition of the case through cost-pressured settlement. The government responded to the PRPs' claim by stating that, on summary judgment, an affirmative defense can eliminate the defendant entirely from the proceeding. This is a great concern for the government, which would then have to pay for the cleanup out of the Hazardous Substance Superfund. The distinction between government suits and private party suits between a seller and a buyer is significant, however, and requires consideration of the inefficient redundant transaction costs that inevitably accompany a bifurcated trial. A blanket pronouncement against all equitable considerations during the liability stage is inappropriate.

103. Id. at 412-13. The reported decision does not indicate that the defendants addressed the issue of potentially increased transaction costs due to a failure of the court to consider equitable factors during the liability phase.

104. Id. at 414. See generally Kornhauser \& Revesz, supra note 41 (discussing whether several-only contribution leads to efficient results). 
limiting the direct involvement of taxpayers. The court did state, however, that the government, like any other PRP, can be named as a joint and several defendant if a private party initiated the cleanup and is seeking restitution. ${ }^{105}$

According to the court, "it would be 'anomalous' to permit apportionment of cleanup costs among PRPs in a section 113 action and not to permit apportionment in a section 107 action, but only if defendants in a section 107 action could not seek contribution in a section 113 action." 106 Since CERCLA does allow for consideration of equitable factors in a section 113 action, the court concluded that there is no need to be concerned about apportionment during the liability phase. This dicta could presumably be interpreted to allow apportionment during the section 107 liability phase in actions where section 113 contribution actions might not exist-as may occur when a private party purchaser/owner, who has found shelter in the innocent landowner provision of section 107(b)(3), sues to recover from a seller/former owner.

Yet this dicta may also allow double recovery for the plaintiff/owner. For example, assume that an owner/purchaser who reduced her offering price to protect against potential remediation requirements sues a seller for actual cleanup costs. Although not discovered until after the purchase, assume that these costs would have been apparent upon a more thorough inspection prior to the purchase. After Kramer, the seller/defendant is required to bring a contribution suit against the owner/purchaser under section 113 to assert the caveat emptor defense. CERCLA section 113(f)(1) states that "[a]ny person may seek contribution from any other person who is liable or potentially liable under section 9607 (a) [107(a)]." ${ }^{107}$ If the plaintiff/owner was diligent in inquiring into the status of the land, found no contamination at the time of the inquiry, and had not causally contributed to the contamination of the site, he or she could avoid liability under section 107 (a) by virtue of the innocent owner defense of section 107(b)(3).

The innocent landowners, then, will not be subject to the "equitable factors [that] the court determines are appropriate" under section 113. ${ }^{108}$ Indeed, under the Smith Land and Kramer decisions, a purchaser/owner who can successfully invoke section 107(b)(3) will not be subject to the forces of equity-although the purchaser/owner may have reduced the purchase price to reflect potential, although unrecognized, environmental exposure. Even if a court finds some way to bring the purchaser into a contribution proceeding and allows the purchaser's restitution to be offset by the benefit of the bargain, the seller is forced to incur extra transaction costs in the form of legal fees. ${ }^{109}$

105. Kramer, 757 F. Supp. at 414.

106. Id. at 416.

107. 42 U.S.C. § 9613(f)(1) (emphasis added). See also Quadion Corp. v. Mache, 738 F. Supp. 270, 274 (N.D. Ill. 1990) ("Quadion may seek such contribution only if defendants are persons 'who [are] liable or potentially liable' under the Act.").

108. 42 U.S.C. $\$ 9613(f)(1)$.

109. Legal fees in cleanup cases can be astonishing. In one instance, a plaintiff amassed $\$ 419,000$ worth of attorneys' fees in order to recover $\$ 940,000$ restitution. General Electric v. Litton Industrial 
Also, the risks assumed by the parties in the bargained for sale and the assessment of the potential for environmental exposure are disregarded, and the seller is essentially converted into an unwitting insurer for the purchaser.

Hinting at a way to mitigate the transaction costs of a bifurcated process, the Kramer court pointed out that there is no need to suffer a delay in recovering contribution, as section 107 and section 113 actions can be concurrent.

A private PRP could be in the same posture as the government here, seeking recovery of its past response costs and a declaratory judgment under section $113(\mathrm{~g})(2)$ that named defendant PRPs are liable for all future response costs. Thus the plaintiff PRP might not have financed or performed the entire cleanup at the time of bringing the section 107 suit. This does not, however, undercut the purpose in creating the incentive for private PRPs to clean up hazardous waste sites, which is to expedite cleanup. Nor does it increase any windfall to section 107 plaintiffs who have rushed in to clean up the contamination, because they are only reimbursed for monies already spent, and can be found liable for their equitable share of future response costs in a section 113 action. ${ }^{110}$

The court also addressed the claims made in several district court cases ${ }^{111}$ that, due to CERCLA's restitutionary nature, equitable defenses are inherent in section 107 actions:

While it may be logical to permit equitable defenses in an inherently equitable proceeding, and sections 106 and 113 both permit equitable considerations, the clear answer for section 107 is that Congress explicitly limited the defenses available to only those three provided in section $107(\mathrm{~b}){ }^{112}$

Finally, the court concluded that, since Smith Land found caveat emptor and unclean hands inappropriate as complete defenses in section 113 claims, they are also inappropriate in section 107 claims. ${ }^{113}$

A third decision denying caveat emptor as a complete defense, Southland Corp. v. Ashland Oil, Inc., ${ }^{114}$ attempted to distinguish between caveat emptor, on the one hand, and indemnification and "hold harmless" agreements that expressly refer to CERCLA liability, on the other. The Southland court accepted Smith Land, but then proceeded to permit what is essentially an express caveat emptor clause to act as a complete defense to CERCLA liability.

In Southland, a private party plaintiff, who purchased the subject property two years before the enactment of CERCLA, sued the former owner to gain a declaration of the latter's liability for expenses incurred in determining the extent of the contamination and for future cleanup costs. The environmental condition of the land was well known, at least to the New Jersey Department of

\footnotetext{
Automation Systems, 920 F.2d 1415, 1417 (8th Cir. 1990).

110. Kramer, 757 F. Supp. at 416 n.18.

111. United States v. Conservation Chemical, 619 F. Supp. 162, 204-06 (W.D. Mo. 1985); Violet v. Picillo, 648 F. Supp. 1283, 1294-95 (D.R.I. 1986), overruled by United States v. Davis, No. 90-0484, 1992 WL 159897 (D.R.I. June 22, 1992); Mardan Corp. v. C.G.C. Music, Ltd., 600 F. Supp. 1049, 1056 n.9 (D. Ariz. 1984); and United States v. Mottolo, 695 F. Supp. 615, 626-27 (D.N.H. 1988).

112. Kramer, 757 F. Supp. at 427.

113. Id. at 428.

114. 696 F. Supp. 994 (D.N.J. 1988).
} 
Environmental Protection, which became aware of the site's problems as early as 1968 , ten years before the purchase. ${ }^{115}$

The defendant, while admitting responsibility for the contamination, attempted to defend against liability by claiming that the parties had allocated liability between them in the purchase agreement. ${ }^{116}$ The court upheld this type of contractual defense, citing CERCLA section 107(e)(1), which states that "[n]othing in this subsection shall bar any agreement to insure, hold harmless, or indemnify a party to such agreement for any liability under this section."117 The court distinguished this case from Smith Land, despite citing it favorably, by asserting that the latter proscribed only caveat emptor and was silent on the issue of indemnification and "hold harmless" agreements. ${ }^{118}$

In Southland, the court allowed the seller to assert a contract provision as a defense even though this defense is not expressly enumerated in section 107(b). In fact, the defense allowed was similar to caveat emptor in that the parties agreed to shift the potential for future liability to the purchaser. This agreement presumably involved valuations of the contract price based, in part, on the risk of future liability. The purchaser's indemnification and "hold harmless" agreements were merely express caveat emptor clauses.

To follow the decision in Smith Land faithfully, however, the Southland court would have had to accept its reasoning that the structure of CERCLA itself could not fairly allow a causally responsible party to utilize any defense, other than one enumerated in section 107(b). By accepting contractual defenses to liability that are not enumerated in section 107(b), Southland implicitly rejects Smith Land. ${ }^{119}$

In Westwood Pharmaceuticals v. National Fuel Gas Distribution Corp.,${ }^{120}$ the plaintiff purchased from the defendant a parcel of land in 1972-also before CERCLA and SARA - for $\$ 60,100$. This site had been used for industrial purposes and to store industrial materials for over 100 years when the plaintiff acquired it. ${ }^{121}$ Although the decision reports that the plaintiff first became aware of on-site, petroleum-based contamination when it began digging test pits and taking soil borings in relation to its own construction efforts after the purchase, the sales contract allowed plaintiff the right to inspect the premises prior to closing the transaction. ${ }^{122}$

115. Id. at $996-97$.

116. Id. at 1000 .

117. 42 U.S.C. $\$ 9607$ (e)(1). The court wrote, "Under this provision, parties remain accountable for any costs incurred in a government-instituted cleanup, regardless of conveyance or transfer; however, between private parties, they retain the freedom to contract out of CERCLA liability." Southland, 696 F. Supp. at 1000 .

118. Southland, $696 \mathrm{~F}$. Supp. at 1000.

119. Ultimately, the defendant's contractual defense failed in that the transaction agreement did not include "an express provision which allocates [CERCLA] risks to one of the parties." Id. at 1002.

120. 737 F. Supp. 1272 (W.D.N.Y. 1990), affd, 964 F.2d 85 (2d Cir. 1992).

121. Id. at 1275 .

122. Id. at $1275-76$. 
The defendant attempted to persuade the court that it had a defense of caveat emptor based on the belief that the "extremely low contract price 'presumably' reflected the parties' understanding that, under New York law, National Fuel would not be liable to Westwood for any condition of the property."123 Beyond simply accepting the reasoning of Smith Land, the Westwood court criticized the defendant's argument of caveat emptor, calling it "fundamental[ly] unfair[]" that the plaintiff would bargain away "its right to bring an action based on statutes such as CERCLA and SARA that were not in existence at the time of the conveyance." ${ }^{24}$ The court, however, indicated that it might consider caveat emptor under circumstances in which the conveyance occurred after the enactment of CERCLA. ${ }^{125}$

\section{B. Cases Allowing Equitable Defenses to CERCLA Liability}

As discussed above, the Westwood court indicated that it might consider the defense of caveat emptor in certain cases where the transaction occurred after CERCLA's enactment, distinguishing the Westwood defendant's use of caveat emptor from its use by the defendant in Mardan Corp. v. C.G.C. Music, Ltd. ${ }^{126}$ In Mardan, prior to bringing a subsequent CERCLA suit, the defendant/seller entered into a settlement with the plaintiff/owner for $\$ 995,000, \$ 781,055$ of which reflected claims arising out of the purchase agreement. ${ }^{127}$ Prior to closing the transaction, the defendant notified the EPA that there was an area of hazardous waste contamination on its site. The EPA, subsequent to the transaction, ordered the plaintiff-at that point the new owner and a contributor of waste in its own right-to remediate the area, prompting the plaintiff to sue the defendant for reimbursement under CERCLA section 107(a)(4)(B). The district court found that the plaintiff was barred from recovery under CERCLA based on both the contractual release given to the defendant by the plaintiff in conjunction with the settlement and by the doctrine of unclean hands. ${ }^{128}$ The district court justified the latter finding by reasoning that because section 107(a)'s form of liability offers equitable restitution, the equitable defense "is applicable in a private cost recovery action under CERCLA."129 The Court of Appeals for the Ninth Circuit affirmed the result based solely on the contractual release, never reaching the issue of the validity of the equitable defense under section $107(\mathrm{a}) .{ }^{1.0}$

123. Id. at 1280 .

124. Id.

125. Id. at $1280-81$.

126. 804 F.2d 1454 (9th Cir. 1986).

127. Id. at 1456 .

128. Mardan Corp. v. C.G.C. Music, Ltd., 600 F. Supp. 1049, 1056-58 (D. Ariz. 1984)

129. Id. at 1058. The court stated that the application of this doctrine would not defeat the intent and purpose of CERCLA because defendants would remain liable to government entities, who are barred neither by contract nor by equitable defenses.

130. Mardan, 804 F.2d at 1457. Courts have generally not looked favorably upon the defense of "unclean hands." See Chemical Waste Management v. Armstrong World Industries, 669 F. Supp. 1285, 1291 n.7 (E.D. Pa. 1987) ("the 'unclean hands' doctrine. . . has no place in CERCLA actions"); see also 
In contrast to Smith Land, Kramer, and Westwood, United States $v$. Mottolo $^{131}$ permitted equitable defenses. In Mottolo, the government sought restitution for cleanup expenditures related to Mottolo's Raymond, New Hampshire site. One defendant argued that it took "due care" with its hazardous waste, asserting "it was unaware of the location to which its hazardous wastes were being taken." ${ }^{132}$ The court found such behavior was not usually considered "due care." According to the court, "the argument is irrelevant given [CERCLA's] strict and explicit limitation of available defenses .... CERCLA section 107(b) does not include a defense based on lack of knowledge."133 Despite this reasoning, the court maintained that the preclusion of equitable defenses under section 107 "is both contrary to equitable principles and unwarranted by CERCLA's statutory language." 134 The court reasoned that CERCLA's equitable remedy of restitution should permit assertions of equitable defenses- "due care" not being one of the allowable defenses.

The court also looked to section 101(32), which provides that CERCLA's liability scheme was meant to parallel that of section 311 of the Clean Water Act ("CWA"). ${ }^{135}$ The court followed the Supreme Court's decision in Weinberger $v$. Romero-Barcelo, ${ }^{136}$ which addressed the issue of whether federal district courts, specifically empowered by the CWA to order fines and criminal penalties, could continue to order injunctions under equitable powers not specifically provided for by the Act. ${ }^{137}$ The Supreme Court, in upholding a district court's ability to enjoin violative behavior under the CWA, stated,

[E]quitable jurisdiction is not to be denied or limited in the absence of a clear and valid legislative command. Unless a statute in so many words, or by a necessary and inescapable inference, restricts the court's jurisdiction in equity, the full scope of that jurisdiction is to be recognized and applied. "The great principles of equity, securing complete justice, should not be yielded to light inferences, or doubtful construction." 138

General Electric Company v. Litton Industrial Automation Systems, Inc., 920 F.2d 1415 (8th Cir. 1990), in which defendants attempted to assert a causation argument that the court transformed into an "unclean hands" argument. The defendants argued that G.E. was suing them only because they were attempting to sell their property to a developer, and the developer had threatened suit against G.E. The defendant also claimed that its hazardous wastes did not "cause" G.E.'s response, but rather the threat of a suit did. Also, the defendants asserted that G.E. was barred from bringing an action against them because they knew about the contamination in 1980 and did not disclose it to the developer until 1984 . The court held that CERCLA § 107 does not allow for the unclean hands defense, as it only allows for the enumerated defenses in $\S 107$ (b). Likewise, it is also the case that Litton could not have asserted the defense because the non-disclosure was taken against the developer, a completely separate party, and not against Litton.

131. 695 F. Supp. 615 (D.N.H. 1988).

132. Id. at 626 .

133. Id.

134. Id.

135. 42 U.S.C. $89601(32)$; see 33 U.S.C. \& 1321 (1988).

136. 456 U.S. 305 (1982).

137. At least one court has ruled that states do not have the power to issue an injunction under CERCLA \$ 107. State of New York v. Shore Realty Corp., 759 F.2d 1032, 1049 (2d Cir. 1985) (implying that if $\S 107$ is interpreted to contain injunctive ability like that expressly provided for in $\$ 106$, it would render the specific phrase in $\$ 106$ "surplusage").

138. Mottolo, 695 F. Supp. at 627, quoting Weinberger, 456 U.S. at 313. 
The Mottolo court interpreted the Weinberger decision to mean that whenever equitable jurisdiction is not expressly removed, courts of equity will have recourse to its remedies.

The issue as applied to CERCLA section 107 is not that simple, however. First, it is not clear that Congress did not take away the equitable jurisdiction of the courts. Its statement that liability is "subject only to the defenses set forth in [section 107(b)]" does not, at least facially, deny or assert the notion of equity. Second, some courts and commentators maintain that CERCLA's form of restitution is not the same as the traditional form. ${ }^{139}$ It is also not clear that Congress was aware that this remedy would be considered by courts to be restitutionary, and thus equitable. Third, as the Kramer court emphasized, Weinberger dealt with a statute that did not specifically proscribe injunctions, whereas CERCLA specifically limits "defenses."140 The Mottolo court reasoned that Congress would have included the term "equitable defenses" in its list of proscribed defenses if it had wanted to preclude them. The Kramer court, on the other hand, reasoned that the express limitation of defenses to those in section 107(b) implied that no other defenses could be asserted. ${ }^{141}$

Some of these issues were addressed by a different district court in United States v. Conservation Chemical. ${ }^{142}$ The court prefaced its discussion of equitable remedies by stating that section 107 was merely meant to be Congress's declaration of CERCLA's liability standard. The court then declared the standard of liability to be the same as section 311 of the CWA ${ }^{143}$ and specifically interpreted the legislative history of CERCLA to indicate that that standard was strict liability, even though Congress at the last moment had decided against expressly including the term "strict liability" in section 107. The court reasoned that the express defenses listed in CERCLA section 107(b) were placed there to indicate the only conduct-based defenses available to escape strict liability (as opposed to enacting a more lenient conduct-based standard such as negligence to the handling of hazardous waste).${ }^{144}$ The court continued by noting that

139. Even though there is debate concerning the nature of the type of restitution involved in CERCLA, it is well resolved that CERCLA restitution is, like other restitutionary actions, equitable. This issue has been resolved by the many decisions declaring that there is no right to a jury trial for CERCLA actions for cost reimbursement. See, e.g., United States v. Conservation Chemical, 619 F. Supp. 162, 205 (W.D. Mo. 1985) (citing cases supporting this proposition).

140. United States v. Kramer, 757 F. Supp. 397, 424-25 (D.N.J. 1991).

141. The Stringfellow court, like the Kramer court, found that "section 107(a) provides the restrictive words referred to by the [Weinberger] Court." United States v. Stringfellow, 661 F. Supp. 1053, 1062 (C.D. Cal. 1987).

142. 619 F. Supp. at 203.

143. 33 U.S.C. $\$ 1321$.

144. It is possible that Congress wanted to avoid the term "strict liability" because of its association with "ultrahazardous activity." Certain chemicals may not be considered ultrahazardous when they are first disposed of, only to be deemed so at a later date. CERCLA's brand of strict liability was meant to reach the responsible party, regardless of whether the party could have known its behavior was ultrahazardous or not. Some versions of strict liability may take into account whether the act was considered ultrahazardous at the time it occurred. 
"[t]he provision of a strict liability standard in a statute does not mean that legal or equitable defenses cannot be asserted."145

It next declared that CERCLA restitution is equitable in nature because parties are seeking restitution for costs "spent on behalf of others' legal obligation to clean up hazardous waste." 146 In concluding that "[e]quitable defenses are proper under CERCLA in determining liability," the court reasoned that since equitable defenses are expressly allowable under section 106, and section 106 and section 107 utilize the same form of liability, "equitable defenses should be available under Section 107 also."147

The decisions in Mottolo and Conservation Chemical more closely comport with the decision in Weinberger than do those in Part VI(A) because they take into consideration the special characteristics of courts of equity, ${ }^{148}$ which have the power to consider the total fairness of the circumstances in reaching their decisions. If a court involved in a CERCLA issue is indeed a court of equity, then equitable defenses, such as the injunctions involved in Weinberger, should be used to promote justice. ${ }^{149}$ A court's equitable powers, including the ability to recognize equitable defenses, are derived from its status and its function, and not from the express provisions of a statute. ${ }^{150}$ On the other hand, legal defenses to statutory actions, such as CERCLA, must be derived from the language of the statute. Construing section 107's express limitation of legal defenses to proscribe equitable defenses as well misses the point of the courts' equitable powers.

As stated in Part II, a court should determine which party can most equitably pay for a non-fund-financed cleanup. The court violates its own duty as a court of equity when it fails to consider the fairness between private parties. The strict liability aspect of CERCLA is meant to hold a party liable for cleanup despite its reasonable precautions. If a seller has compensated the purchaser by way of a lower selling price, the court of equity should recognize that the seller's responsibility has been completed.

145. Conservation Chemical, 619 F. Supp. at 204.

146. Id. at 205.

147. Id. at 204-05.

148. The Weinberger court emphasized that federal courts should resort to their special equitable power of injunction only when there is a "threat of irreparable injury" and "inadequacy of legal remedies." Weinberger, 456 U.S. at 312. The court found the essence of equity jurisdiction to be "the power of the Chancellor to do equity and to mold each decree to the necessities of the particular case. Flexibility rather than rigidity has distinguished it." Id. (quoting Hecht Co. v Bowles, 321 U.S. 321,329 (1944)).

149. Upon deciding that equitable defenses were appropriate, the Mottolo court first struck the defendants' claim that the government was estopped from bringing a claim against them. The defendants alleged that they only consented to allow the EPA to inspect their site when the EPA represented that they would not seek response costs. The court denied this defense by showing that the EPA's authority to respond to hazardous wastes was statutorily derived. The act, said the court, in order to be effective, implicitly gives the EPA a right to inspect property. The court, for similar reasons, also struck the defendants' defense based on the government's alleged waiver of its right to sue. United States v. Mottolo, 695 F. Supp. 615, 627-28 (D.N.H. 1988).

150. See supra part III. 


\section{VII \\ CONCLUSION}

By interpreting CERCLA to proscribe equitable defenses, courts ignore the dynamics of the transaction from which the present ownership of the commercial property has derived. One of the underlying justifications for CERCLA's statutory liability scheme is the desire to provide the government with a mechanism to address the long unresolved problem of hazardous waste contamination without unduly burdening taxpayers. ${ }^{151}$ CERCLA thus allows the government to win cleanup cases as easily and as quickly as possible. The liability scheme of retroactive, strict joint and several liability is a powerful tool for monetary recovery, allowing for a quick turnaround of funds in order to keep the resources available for investigation of the many other sites in need of cleanup. The liability scheme, however, also allows private parties to apportion the costs of the cleanup among themselves through an equitable action for restitution; these actions do not require the involvement of government agencies or the taxpayer.

The courts have not adequately distinguished between clean-up actions taken by private parties and those taken by governmental agencies that utilize, at least partially, Superfund. A private party cleanup has different policy considerations, including the importance of incentives for private parties to remediate sites without government intervention. Although such incentives are desirable, the failure of courts also to recognize equitable defenses allows for the possibility of double recoveries and windfalls to purchasers in the form of "risk insurance." The rigid statutory liability structure of CERCLA is meant to ensure that Superfund will be replenished, not to ensure that purchasers will have a legal guarantee of the seller's liability so that they may ignore potential hazardous waste problems when appraising a property. When the government is not involved, thus removing the incentive to replenish Superfund, the role of the court must be to determine who should pay for the cleanup.

151. See United States v. Price, 577 F. Supp. 1103, 1113-14 (D.N.J. 1983) (stating that strict liability is the best option for CERCLA because it imposes liability on parties who are responsible, and not on the taxpayers, who would otherwise shoulder the burden of paying cleanup costs).

It may be argued that even when a causal agent pays for a cleanup, the taxpayers ultimately pay. In many cases the corporate polluter simply will pass along the remediation costs, or a portion thereof, to the consumer in the form of increased prices. Economically, the quantity of the responsible party's product sold will be reduced in response to the price increase. One author suggests that the people who will no longer be able to purchase the product due to the price increase will be those who have the least resources to buy at that price, namely the poorer members of society. PETER S. WENZ, ENVIRONMENTAL JUSTICE 1 (1988), citing Norman T. Faramelli, Ecological Responsibility and Economic Justice, reprinted in WESTERN MAN AND ENVIRONMENTAL ETHICS 188 (Ian G. Barbour ed., 1973). The argument is met by those who believe that this particular group of consumers-those who purchase the polluter's product - should be the ultimate payors, because it was their consuming desires that created the production motivation to begin with. If the market economy for this good is to reflect the full information of costs accurately, those people at the margin who can no longer purchase the product due to its higher price, now cannot do so because the new price now accurately reflects the true costs of the product, not because the price has suddenly become greater. Prior to the learning of the true costs, the consumer received a windfall by not paying for the complete social costs. 
In making this determination, courts must allocate costs among private parties equitably. There are several approaches for a court's use of its equitable powers in a private party CERCLA action. First, the court may ground its authority in its inherent equitable nature as a court applying restitution, or, more specifically, to the general equitable powers conferred upon it by Congress when applying CERCLA. Second, the court may collapse the distinction between section 107 and section 113 actions, and apply equitable principles, expressly allowed by the latter section, when determining initial liability. Third, the court may declare the seller liable at the liability stage, but deny any recovery to the purchaser at the contribution stage. Alternatively, the parties may contractually apportion CERCLA liability in the purchase agreement. The contractual devices of indemnification and "hold harmless" clauses promote the use of disclosure and investigation.

At present, all legal and economic incentives for disclosure and investigation lie with the purchaser. The availability of the defense of caveat emptor in private party CERCLA actions would create incentives for the seller to disclose the condition and prior uses of the property. The seller would need to prove fairness to the purchaser in order to invoke the powers of equity if he or she were sued. Furthermore, knowledge that there could be no recourse against the seller would strengthen existing incentives for the purchaser to investigate the land thoroughly. The price attached to the land under this system would effectively internalize the costs associated with hazardous waste cleanup.

The defense of caveat emptor thus makes CERCLA liability an ex ante, rather than ex post, consideration in real property transactions. This allows the parties to a transaction to have full information from the beginning about the subject property. The hazardous waste contamination distortion would be eliminated by bringing the true costs of the transaction to the bargaining table. Those members of society who do not desire to buy property that carries the added expense of a cleanup would utilize their resources more efficiently in other markets. There would be fewer real property transactions, but the transactions that occurred would reflect the true desires of the parties involved. This approach promotes both fairness to the parties and economic efficiency. 
